\title{
Editorial
}

Journal of Innate

Immunity

\section{Allergic Inflammation: The Enemy Within}

\author{
Marc A. Williams ${ }^{a} \quad$ Arne Egesten $^{b}$ \\ ${ }^{a}$ EPHD Cardiopulmonary and Immunotoxicology Branch, National Health and Environmental Effects \\ Research Laboratory (NHEERL), US Environmental Protection Agency, Research Triangle Park, N.C., USA; \\ ${ }^{b}$ Department of Clinical Sciences, Lund University, Lund, Sweden
}

Allergic inflammation is often seen as an adequate part of host response to helminthic infestation. However, when dysregulated in chronic allergic diseases, it presents suffering for the individual and a challenge for the health care provider. In this issue, the Journal of Innate Immunity publishes several articles that define key roles played by the cellular network (i.e. mast cells, eosinophils and dendritic cells) in steering proallergic immune responses. In a timely review article, Akuthota et al. [1] discuss the emerging appreciation that eosinophils are multifunctional cells providing immune defensive as well as proallergic functions - particularly in the context of allergic airway disease. Similarly, it is now recognized that mast cells too are crucial players in microbial immune surveillance as well as in allergic immunity. McAlpine et al. [2] discuss their elaborate expression of pattern-recognition receptors, broad tissue distribution, combined with their key effector roles in allergic inflammation, suggesting that they are capable of mediating microbial-induced exacerbations of allergic diseases [2]. In a related study, Enoksson et al. [3] show that mast cells are endowed with intracellular pattern-recognition receptors such as Nod1 that on activation by exogenous danger signals like M-TriDAP (a degradation product of bacterial peptidoglycan) induce a release of proinflammatory mediators, further supporting a role for mast cells in host immune defense against bacteria [3]. While the pulmonary system $[4,5]$ is susceptible to allergic airway disease on activation by such diverse challenges as ambient air pollutants [4] and indoor allergens such as German cockroach frass [5], the innate immune system fulfills an important role in the pathogenesis of allergic atopic dermatitis [6]. In complementary studies, Bezemer et al. [4] and Page et al. [5] show that ambient airborne pollutants and German cockroach frass, respectively, can promote a rapid onset of allergic inflammation via activation of stimulatory myeloid dendritic cells $[4,5]$. Conceptual frameworks that advanced our understanding of how the pulmonary innate immune system is modulated by ambient pollutants, xenobiotics and respirable areoallergens have also been previously discussed $[6,7]$. Interestingly, the dendritic cell appears to be the crucial link for sensing 'environmental danger' in the lung and bridging the innate arm of immunity with the adaptive proallergic response $[8,9]$. Sensing of socalled 'dangerous environmental signals' by dendritic cells appears to require functional transmembrane expression of the mucin-like molecule Mucl that is capable of fine-tuning Toll-like receptor signaling and regulating the inflammatory response [9]. In the final article, Maintz and Novak [10] discuss dysregulation of innate immunity in the pathogenesis of atopic dermatitis, a dis-

\section{KARGER}

Fax +4161306 1234

E-Mail karger@karger.ch

www.karger.com (c) 2011 S. Karger AG, Basel

$1662-811 X / 11 / 0032-0111 \$ 38.00 / 0$

Accessible online at:

www.karger.com/jin
Dr. Arne Egesten

Department of Clinical Sciences, Lund University, BMC B14

Tornavägen 10

SE-22184 Lund (Sweden)

Tel. +46 46222 4445, Fax +46 4615 7756, E-Mail Arne.Egesten@med.lu.se 
ease frequently promoted by microbial superinfection. They propose a revised paradigm where a disturbed innate immune system is constituted by genetic susceptibility, disturbed barrier functions, dampened antimicrobial defense and interplay between NK cells and plasmacytoid dendritic cells. Together, this allows the entry of infectious microorganisms, which exacerbates an ongo- ing pernicious cycle of Th2-driven allergic inflammation in the skin [10]. Continued research will further elucidate the complex network of cells and signaling pathways that result in allergic inflammation. Recently discovered mechanisms, as described in the articles of this issue, can serve as models for the development of novel therapeutic strategies.

\section{References}

1 Akuthota P, Xenakis JJ, Weller PF: Eosinophils: offenders or general bystanders in allergic airway disease and pulmonary immunity? J Innate Immun 2011;3:113-119.

2 McAlpine SM, Enoksson M, Lunderius-Andersson C, Nilsson G: The effect of bacterial, viral and fungal infection on mast cell reactivity in the allergic setting. J Innate Immun 2011;3:120-130.

3 Enoksson M, Ejendal KFK, McAlpine S, Nilsson G, Lunderius-Andersson C: Human cord blood-derived mast cells are activated by the Nod1 agonist M-TriDAP to release pro-inflammatory cytokines and chemokines. J Innate Immun 2011;3:142-149.
4 Bezemer GFG, Bauer SM, Oberdörster G, Breysse PN, Pieters RHH, Georas SN, Williams MA: Activation of pulmonary dendritic cells and Th2-type inflammatory responses on instillation of engineered, environmental diesel emission source or ambient air pollutant particles in vivo. J Innate Immun 2011;3:150-166.

5 Page K, Zhou P, Ledford JR, Day SB, Lutfi R, Dienger K, Lewkowich IP: Early immunological response to German cockroach frass exposure induces a Th2/Th17 environment. J Innate Immun 2011;3:167-179.

6 Lanckacker EA, Robays LJ, Joos GF, Vermaelen KY: A new danger in the air: how pulmonary innate immunity copes with manmade airborne xenobiotics. J Innate Immun 2010;2:96-106.

7 Horner AA: Regulation of aeroallergen immunity by the innate immune system: laboratory evidence for a new paradigm. J Innate Immun 2010;2:107-113.
8 Pesce I, Monaci E, Muzzi A, Tritto E, Tavarini S, Nuti S, De Gregorio E, Wack A: Intranasal administration of $\mathrm{CpG}$ induces a rapid and transient cytokine response followed by dendritic and natural killer cell activation and recruitment in the mouse lung. J Innate Immun 2010;2:144-159.

$\rightarrow$ Williams MA, Bauer S, Lu, W, Guo J, Walter S, Bushnell TP, Lillehoj EP, Georas SN: Deletion of the mucin-like molecule Mucl enhances dendritic cell activation in response to toll-like receptor ligands. J Innate Immun 2010;2:123-143.

10 Maintz L, Novak N: Modifications of the innate immune system in atopic dermatitis. J Innate Immun 2011;3:131-141. 